\title{
DIVISION OF ONE EMPLOYMENT CONTRACT BETWEEN TWO EMPLOYERS
}

\author{
Andrej PORUBAN, Karol KRAJČO
}

\begin{abstract}
The paper deals with the possibility of division of rights and obligations arising from employment contracts for one employee for several employment relationships part-time. The conclusion of the pre-contractual process in employment relations is the conclusion of an employment contract, which establishes an employment relationship. Within it, one undertakes to perform dependent work for pay for the other. It is a socio-economic relationship, because its nature is not only property but also personal, not only in the sense of personal performance of work. By including the employee in the organizational structure of the employer, a close personal bond is established, which activates a whole range of subjective rights and legal obligations of the subjects of employment..
\end{abstract}

Key words

employment contract, labour law, remuneration, working conditions

JEL Classification: : K31, K38, J83

DOI: https://doi.org/10.52665/ser20210105

\section{Introduction}

The employment contract "is a bilateral legal act and at the same time a concretization of the principle of contract in labor law, through which the constitutional right to free choice of profession, employment and the right to work is realized" (Janičová, 2010, p. 180). Due to the fact that the Labor Code mainly regulates the content of the employment relationship, it does not require much for a valid employment contract. Pursuant to $\S 43$ par. 1 of the Labor Code, the employer is obliged to agree with the employee on the essentials, which are:

a) the type of work for which the employee is hired and its brief characteristics,

b) place of work (municipality, part of municipality or otherwise designated place),

c) day of commencement of work,

d) wage conditions, if not agreed in the collective agreement.

Ad type of work

The type of work is essential because it defines what work the employee is obliged to perform. "It can be defined by a certain job function, or by a specific classification, or as a set of activities that can be determined alternatively or cumulatively." (Matlák, 2014, p. 136). However, if an excessively high number of types of work is agreed, it cannot be ruled out that the law is being circumvented. Assessing whether the type of work has been validly agreed is always a matter of a specific case.

Ad place of work

There is no law specifying how the place of work is to be defined. It can therefore be agreed very narrowly, but also very broadly, while allowing more places to work. As a place of work, a specific workplace, address of the employer's registered office, municipality, region, etc. can be agreed. However, it must always meet the needs of the employer and be proportionate to the nature of the work, provided that "the agreed place of work need not be identical with the registered office of the employer". (Križan, 2020, p. 37)

Ad the day of the start of work

From the day when the employment relationship arose, the employer is obliged to assign work to the employee under the employment contract, pay him a salary for the work performed, create conditions for performing work tasks and comply with other working conditions laid down by law, collective agreement and employment contract. According to the employer's instructions, the employee is obliged to perform the work in person according to the employment contract at the specified working hours and to observe work discipline. 'The employment relationship shall take effect on the date agreed 
in the employment contract as the date of commencement of work, regardless of whether the employee actually commences employment on that day; for example, he does not start because he becomes ill - it is an obstacle at work. "(Trel'ová, 2012, p. 242) The way in which the day when an employee starts work can be expressed is not prescribed by law. This day can be agreed not only by direct time data, but also on the basis of other objectively verifiable facts not marked by a specific date, about which the subjects of employment when concluding the employment contract may not even be sure when exactly they will occur. However, they must not leave any doubt that the date of commencement of work has been indistinguishably marked by them and must allow a clear conclusion as to which day the employment relationship will take place.

\section{Ad wage conditions}

If the wage conditions are not agreed in the collective agreement, they are a necessary part of the employment contract. If they are agreed in a collective agreement, it is sufficient to make a reference to its provisions; otherwise it is sufficient to refer to the relevant provisions of the Labor Code. In wage conditions, the employer shall agree in particular on the forms of remuneration of employees, the amount of the basic component of wages and other components of benefits provided for work and the conditions of their provision. The basic component of the salary is the component provided according to the time worked or the achieved performance ( $\S$ 119 para. 3 of the Labor Code). "The contractual freedom of the contracting parties is not unlimited, but limited by the legal requirements of the minimum level of remuneration." (Olšovská - Láclavíková, 2017, p. 17) In addition, wage conditions must be agreed without any discrimination based on sex. This applies to any performance for work, as well as to benefits that are or will be paid in connection with employment.

\section{Findings}

Transfer of rights and obligations from the employment contract to several employers

From the text of the Labor Code as well as from its purpose, it can be deduced that an employment contract is always negotiated and concluded by one employee with one employer. There is no indication that it could cover two or even more relationships with different employers. However, during the employment relationship, various structural changes may take place at company level in order to achieve better competitiveness and efficiency. In such transactions, employees do not appear as participants and are exposed to unilateral decisions of the employer, or the employer and the future employer. (Schwarz, 2017, p. 4) However, the employees concerned should not be placed in a less favorable position as a result of a sale, merger or lease. In order to mitigate their social impacts, a 'legal transplant' - the transfer of an economic unit - was incorporated into the Slovak legal system (Dolobáč, 2011, pp. 118-123). It found its place in the Labor Code in the section entitled 'Transfer of rights and obligations arising out of an employment relationship', which transposes Council Directive 2001/23 / EC of 12 March 2001 on the approximation of the laws of the Member States relating to the safeguarding of employees' rights in transfers of undertakings, businesses or parts. undertakings or establishments (hereinafter referred to as Directive 2001/23 / EC). The purpose of the legislation is to preserve the rights of employees by allowing them, as far as possible, to continue with the new employer under the same conditions as agreed with the transferor. Pursuant to $\S 28$ par. 1 of the Labor Code, "if an economic unit is transferred for the purposes of this Act, the employer or part of the employer, or if the role or activity of the employer or part thereof is transferred to another employer, the rights and obligations of employment relations with the transferred employees are transferred to the employer'. The assumption is that the economic unit according to $\S 28$ par. 2 of the Labor Code "maintains its identity as an organized grouping of resources (tangible components, intangible components and personal components), the aim of which is to carry out an economic activity, regardless of whether this activity is main or ancillary".

However, what if, in adapting to new market conditions, a situation arises in which only part of the rights and obligations arising from the employment contract pass to the transferee and the rest remain with the former employer, or 
several parts of the undertaking are transferred simultaneously to two or more employers?

From the use of a single number ('taking over employer') it appears that such a construction does not fall under the transfer of rights and obligations under the Labor Code, but this is not explicitly excluded.

\section{Judgment of the Court of Justice of the European Union}

The fact that this is not a completely hypothetical case suggests that the consequences of a transfer involving several acquiring employers have already been addressed by the Court of Justice of the European Union in its judgment of 26 March 2020 in Case C-344/18, ISS Facility Services NV vs Sonii Govaerts and Atalian NV.

In the original dispute, ISS provided cleaning and maintenance services for the city of Gent, which were divided into three parts. The first part included museums and historic buildings, the second libraries and community centers, and the third administrative buildings. Ms Govaerts worked full-time as a project leader and dealt with planning and organizing the work carried out at three places of work, which correspond to said parts. The city later announced a public procurement that covered all parts. ISS was not successful with its offer. The first and third lots were awarded to Atalian, while the second was awarded to Cleaning Masters.

Due to the transfer of the business and the assignment to work places corresponding to parts one and three, ISS informed the employee that her employment contract had been $85 \%$ transferred to Atalian and that the successful candidate had automatically entered into an employment relationship with Ms Govaerts. (The other staff performing the cleaning work on the premises corresponding to the three parts of the contract entered into employment with Atalian and Cleaning Masters on the basis of a collective agreement concluded within the Joint Committee on Cleaning and Cleaning Services for the takeover of staff as a result of the transfer became binding on the basis of a Royal Decree). Atalian informed the ISS that there had been no transfer of the business and therefore no contractual relationship had been established. Ms Govaerts brought an action against ISS and
Atalian, seeking payment of a severance grant, a pro rata annuality premium and a holiday allowance. (The Cleaning Masters, to which the second part of the contract was awarded at the rate of $15 \%$, was not a party to the proceedings before the Gent Court of Appeal (Arbeidshof te Gent), which referred a question for a preliminary ruling.)

According to the Court, the transfer of rights and obligations cannot be affected by the fact that a transfer has taken place to one or more acquirers at the same time. It therefore rejected at the outset the hypothesis that the maintenance of the rights and obligations arising from the employment contract could not be relied on against any of the transferees, as this would deprive Directive 2001/23 / EC of the necessary effect (Judgment in Case C-344/18, paragraphs 27 and 28).

As regards the criterion of 'principal acquirer', it stated that, although that interpretation made it possible to ensure that the rights and obligations of the employee were preserved and that the interests of the employee were protected. This does not take into account the interests of the acquiring employer, as he is transferred to the rights and obligations arising from a full-time employment contract, whereas the employee concerned performs only shorter working hours with that transferee (Judgment in Case C-344/18, paragraphs 30 and 31).

He therefore adopted the option of transferring the rights and obligations to each of the acquirers in relation to the activities carried out by the employees, which in principle makes it possible to ensure a fair balance between protecting the interests of employees and those of the acquirers. As the rights and obligations arising from the employment contract remain the same, while new employers are not subject to greater obligations than those arising from the transfer. It also stated that it was for the Belgian court to determine the conditions for a possible division of the employment contract, which may take into account the economic value of the parts of the contract to which the staff member was awarded or the time actually devoted to each part (Judgment in Case C-344/18, paragraphs 32 and $34)$.

The Court has also clarified that the division of an employment contract must be possible or it 
must not lead to a deterioration in working conditions or jeopardize the preservation of employees' rights, which must be verified by the national court. Should such a division prove impossible or adversely affect the employee's rights, then the liability for the resulting termination of the employment relationship would be attributed to the transferee or acquirers under Article 4 of Directive 2001/23 / EC, even if the termination occurred at the initiative of the employee. (Judgment in Case C-344/18, paragraph 38).

\section{Practical implications of the division of the employment contract}

Unlike the Fourth Chamber of the Court, we consider that Ms Govaerts should have remained employed by the ISS and did not belong to the transferred economic unit because she was entrusted with administrative and organizational tasks and did not participate in the cleaning services which were the subject of the transfer. However, our disagreement does not alter the fact that the intentions of the judgment in Case C-344/18 can also be interpreted as $\S 28$ and subsequent amendments to the Labor Code as regards the simultaneous transfer of several parts of an undertaking involving different acquirers.

If, after considering the facts, the existence of a transfer of an economic entity which retains its identity is established, the employment contract could be divided into several part-time contracts in proportion to the function performed by the employee for each of the new employers. With regard to the protection of the employee, account must be taken of the effects of such a solution, which by its very nature may lead to disadvantages, in particular as regards the performance of work tasks. The employee will therefore always have the opportunity to refuse to divide his employment contract in accordance with $\S 29$ a of the Labor Code: "If the employee's working conditions are to be fundamentally changed by transfer and the employee does not agree with their change, the employment relationship is considered terminated by agreement for reasons under $\S 63$ paragraph 1 letter b) on the date of transfer. The employer shall issue the employee with a written proof of termination of employment according to the first sentence. According to the first sentence, the employee is entitled to severance pay according to $\S 76$. "It is true that disagreement should not be expressed with a certain reservation and applies to the entire employment relationship. (Barancová, 2019, p. 42)

However, the implementation of the procedure outlined above will be difficult. For taking over employers, this will be e.g. integration of an employee with shorter working hours into the organizational structure. From the point of view of organizing the work regime and scheduling work changes, the employee cannot even be ordered to work overtime ( $\S 97$ paragraph 2, second sentence of the Labor Code). The performance of gainful employment of a competitive nature for several acquirers will also be problematic. However, we believe that due to the priority of the special regulation $(\S 28$ et seq. of the Labor Code), the prior written consent of the employer will not be required ( $§ 83$ para. 1 of the Labor Code). On the other hand, such an 'granted' consent will still be able to be revoked in writing by the employer at any time - even if only for serious reasons - pursuant to Section 83 (2) of the Labor Code. An employee who will be obliged to terminate another gainful activity without undue delay will thus have only one employment relationship for a shorter working time. In each case in particular, consideration will have to be given to the length of shorter weekly working hours which it is still fair to require an employee to restrict the constitutional right to work. This is all the more true if, after the day of the transfer, he can no longer use the exit strategy with a guaranteed severance pay $\rightarrow$ $\S 29$ a ZP (for more details see Hamulák, 2014. pp. 54-59). In addition, a similar situation may occur even after the termination of the employment relationship, if the employee had an agreed competition clause with the transferor pursuant to Section 83a of the Labor Code. Complications can also occur on the part of the converter, which e.g. will also have to include in the budget the cost of making additional copies of the staff member's personal file with the same validity as the original, as it will not be possible to create separate parts by proportional division

\section{Conclusion}

We are not entirely convinced that the division of an employment contract is legally feasible, because different rules must apply to the transfer 
of rights and obligations from employment relationships than to the transfer of assets or other liabilities. The employment relationship is not a traditional exchange contract or any other classic relationship between creditor and debtor, but it consists of a much more complex set of not only property but also personal / personality elements that go beyond the contractual basis. As it is not just a simple sum of rights and obligations, it does not mean that it consists of separable different employment relationships for shorter working hours. Similar criticisms have been observed in Great Britain (McMullen, 2021). Last but not least, there is also a conflict with $\S 49$ of the Labor Code, according to which an employment relationship for shorter working hours can arise only from the own will of both entities. Although such a requirement also follows from Clause 1 letter (b) Council Directive 97/81 / EC of 15 December 1997 concerning the framework agreement on parttime work concluded by UNICE, CEEP and the ETUC has not been dealt with by the Court of Justice; for more on the directive see van der Mei, 2019.

However, if we accept that part of the economic unit retains its identity, it will be even more

\section{References}

Barancová, H. a kol.: Zákonník práce. Bratislava : C.H. Beck, 2019. ISBN 978-80-89603-78-7, s. 1352.

Dolobáč, M.: Zachovanie nárokov zamestnancov pri prevode činnosti podniku. In: Rezistencia vnútroštátneho práva a právne transplantáty : zborník vedeckých prác. Košice : Univerzita Pavla Jozefa Šafárika v Košiciach, 2011. ISBN 978-80-7097-916-7. s. 118-123.

Hamulák, J.: Postavenie jednotlivca v individuálnych pracovnoprávnych vzt'ahoch. Autonomie jednotlivce. - Praha : Leges, 2014. s. 54-59.

Janičová, E.: Pracovná zmluva a flexibilné formy organizácie práce - východiská, trendy. In: Liberalizácia pracovného práva a nové trendy vo vývoji pracovných vzt'ahov. Košice: UPJŠ v Košiciach, 2010. ISBN 97880-7087-840-5, s. 180-196. important in practice than ever to find consensus between the parties to the transfer, because otherwise the employment contract will be automatically split into two or more acquiring employers without any relationship. Moreover, the problem remains that the judgment in Case C-344/18 itself does not provide clear guidance as to whether the division is to be based on the economic value of the lots or on the time the employee actually devotes to each lot.

However, it is highly probable that the fragmentation of daily work between several employers will have an adverse effect on the employee's employment conditions. The starting point for him will be an appeal to terminate his employment. With the eventual activation of $\S$ 29 a of the Labor Code, the transferor will always have to calculate in advance, because the costs associated with the provision of severance pay will increase significantly.

Last but not least, with the division of the employment contract, there may also be difficulties in submitting a delimitation protocol (list of transferring employees) to the branch of the Social Insurance Agency in which the transferor is registered.

Križan, V.: Obsahové náležitosti pracovnej zmluvy. In: Právna politika a legislatíva. Zmluvná autonómia $\mathrm{v}$ súkromnom / pracovnom práve. Bratislava : Wolters Kluwer SR, 2020. ISBN 978-80-571-0308-0, s. 32-44.

McMullen, J.: Leaving a Legacy: Recent Jurisprudence of the European Court on Transfer of Undertakings. In Industrial Law Journal, 2021, ISSN 1464-3669, s. 130-157.

Matlák, J.: Podstatné náležitosti pracovnej zmluvy. In: Pracovné a sociálne zákonodarstvo $\mathrm{z}$ hladiska aktuálnych legislatívnych zmien. Bratislava : Merkury, 2014. ISBN 978-80-89458-34-9. s. 134-142.

Olšovská, A. - Láclavíková, M.: Sociálna a motivačná funkcia mzdy, odmeňovanie ako nástroj motivácie zamestnancov. In: Právne nástroje odmeňovania $\mathrm{v} 21$. storočí. 
Bratislava : Friedrich Ebert Stiftung, zastúpenie v SR, 2017. ISBN 978-80-8914953-7. s. 17-25.

Trel'ová, S.: Kompatibilita obsahu pracovnej zmluvy s príslušnou smernicou Európskej Únie. In: Die Stellung des Arbeitsrechts im Rechtssystem der Slowakischen Republik : Sammelband wissenschaftlicher Beiträge. Wien : Paul Gerin, 2012. ISBN 978-3-20002915-6. s. 238-245.

Van der Mei, A. P.: Fixed-Term work: Recent developments in the case law of the Court of Justice of the European Union. In European Labour Law Journal, 2019, ISSN 2399-5556.

\section{Contact}

Andrej Poruban JUDr., PhD.

Faculty of Social and Economic Relation Alexander Dubček University of Trenčín

Študentská 3

91150 Trenčín

andrej.poruban@tnuni.sk

Karol Krajčo, Ing.

Faculty of Social and Economic Relation Alexander Dubček University of Trenčín

Študentská 3

91150 Trenčín

karol.krajco@tnuni.sk 